\title{
The Manifestation of Good Faith Principles in Transfer and Registration of Land Rights Based on Pancasila Perspective
}

\author{
Fathul Laila* Abdul Rachmad Budiono Iwan Permadi Istislam \\ Faculty of Law, Universitas Brawijaya, Jl. MT. Haryono No.169, Ketawanggede, Kec. Lowokwaru, \\ Kota Malang, Jawa Timur 65145, Indonesia
}

\begin{abstract}
Pancasila is the Philosophy of the Indonesian nation as an ideology, that set the order of the life in Indonesia, included in the field of Agrarian as contained in the Article 33 paragraph (3) of Constitution of the Republic of Indonesia (UUD 1945), but the manifestation of the principles of good faith in Agrarian field, through Land Deed Official (PPAT) is yet to be achieved. This study is an empirical study, the type of data in this study is primary and secondary data. Data were collected by interviews and literature studies. The technique of analyzing data is interactive analysis (interactive models of analysis). The discussion of the study indicate that the good faith was used as the principle of general law, but the registration of the land rights applied throughout Indonesia, the monitoring is regulated by the government through the Minister of Agrarian and Spatial Planning or National Land Agency. It means that the principle of Good Faith in the transfer and registration of land rights with PPAT certificate does not manifest. This can be realized in the Agrarian Agreement (UUPA) if the government is issuing a law regarding the Land Rights Transfer or Land Ownership and PPAT Law.
\end{abstract}

Keywords: good faith principle, transfer and registration of land rights, pancasila

DOI: $10.7176 / \mathrm{JLPG} / 93-13$

Publication date: January $31^{\text {st }} 2020$

\section{Introduction}

The reality many of the laws and regulations implementations have yet to be in accordance with Pancasila and the 1945 Constitution. One of them is the Land rights problem.

Legal conflicts regarding land rights are often found throughout Indonesia, some with lengthy disputes, especially on the overlapping ownership of the land ownership. This is due to the importance of land and the scarcity of land for the people. Hence, it often causes disputes among the people, either people versus people, people versus legal entities, as well as people versus government.

Land rights problem between people and legal entity or government, in this case, the Ministry of Agrarian and National Land Agency, may due to the unclearness of land rights transfer regulation within the agrarian law, thus the good faith principle cannot be implemented. Even though this Agrarial Law has stipulated various types of land ownership and land rights, its implementation is yet to take an interest in the community. Land ownership is so important for the indigenous people as the land serves as their source of livelihoods, such as for farming, plantation, animal husbandry, fisheries, industries, as well as for residence.

In practical level, various cases emerge throughout Indonesia regarding to the Article 33 (3) of the UUD 1945, such as land rights conflicts between the government of Indonesia and the people; the invoking of the land rights, occupation of the state lands, and the plantation land conflicts (Istislam et. al. 2014), occupation of the land ex-business rights (Permadi, 2016), etc. Similarly, there are also many cases due to the abuse of power committed by the Office of the National Land Agency. These are suspected due to the lack of understanding and lack of law enforcement on the substance of the Agrarian law and due to the Good faith Principle that is yet to be implemented.

The Good faith Principle as a universal principle must be implemented by the government, the Ministry of Agrarian and Spatial Planning or the National Planning Agency to achieve good governance in each legal relationship, including the agrarian law in Indonesia.

Good faith is not only during the implementation of the agreement but also during the making or the signing of an agreement (Suharmoko, 2004). The strong influence of good faith is not only on the implementation of the contract but also during the making of the contract (Solikha, 2015; Khairandi,2003). Similarly, Sulistyarini, at.al, (2018), claims that good faith within the contract is only an interpretation that suits the principle of fairness and appropriateness. Nevertheless, each person has the freedom to determine their intention and this is not against human rights. It is in line with McKendrick (2018) that this principle is a subjective right. In the same tune, Laila (2016) also wrote that Good faith in the implementation of the agreement ultimately means that the agreement should be carried out based on fairness and appropriateness.

The signing of an agreement, related to the registration of the land rights for the community to prevent the disputes on the ownership of that particular land, can be carried out in a front of Land Deed Official (PPAT).

Land Deed Official (PPAT) is regulated within the government regulation PP No. 37 of 1998. However, considering the PPAT existence is not referring to the observed legal system and the element of the Public 
Officers are yet fulfilled (Yudara, 2001) due to the PPAT Law is yet enacted, judicially PPAT is not a public officer as stipulated within the Article 1868 of the KUH Perdata, but in practice, the PPAT exists and is accepted by the legal community. The PPAT is acknowledged as the authorized officer to implement the function of the Public Officer that is to produce a legal deed, specific for land rights transfer and forfeiture of land rights and land ownership.

Based on this research, the implementation of the Good faith Principle can be in the form of Agrarian agreement, when the landreform is carried out through the establishment of the Land Rights Transfer Law or Land Ownership and enactment of the PPAT Law.

\section{Methodology}

This study is an empirical study with the purpose to identify the laws of the community with the intention to know other symptoms. This research is descriptive, which aims to accurately describe the properties of an individual, circumstance, particular symptom or group, or to determine the spread of a symptom, there is a relationship between a symptom and the other symptoms in the community (Sukanto, 1986). The type of data in this study is primary and secondary data. Primary data was collected by interview and secondary data obtained through literature study, electronic media, internet, laws regulation and the other literature. The technique of analyzing data is interactive analysis (interactive models of analysis).

\section{Discussion}

\subsection{Perspective of Pancasila}

Pancasila is the Philosophy of the Indonesian nation as an ideology, that sets the order of life in Indonesia. There are found in legal norms, social norms, crystallized in the institutions, systems, organizations, etc. Ideology is not only related to state life, but also with that of social life. Hence this ideology is both state and Indonesian nation ideology. Based on such an analysis it can be said that national ideology is the whole idea or idea that is based on principles of thought (philosophy of the nation: Pancasila) set forth in the preamble of the Constitution of the Republic of Indonesia as a constitutional juridical guideline for the implementation in order to achieve the ideals and the values contained therein.

Pancasila which is formulated in the Preamble of the Constitution of the Unitary State of the Republic of Indonesia in 1945 has been a fixed fundamental state law (staats fundamental norm). This obviously means that the opening of the 1945 Constitution (after the amendment is called the 1945 Constitution of the Republic of Indonesia abbreviated to the 1945 Constitution of the Republic of Indonesia) can not be changed by anyone nor by any institution (Wiyono, 2016). Oesman and Alfian (1992) say that "... changing the preamble of the 1945 Constitution (now Law NRI 1945), means to change the proclaimed State founded by the founding state (PPKI), because the basic formulation of the state in the opening of the 1945 Constitution of the Republic of Indonesia is only done once, for the state which was then proclaimed on 17 August 1945 as the unitary state of the Republic of Indonesia (NKRI) based on Pancasila and the Constitution of the State of the Republic of Indonesia 1945. This clearly indicates that changing the Preamble of the 1945 Constitution of the state can be interpreted as changing and or dissolving the 1945 proclamation state.

Clearly, the basic values of Pancasila are permanent and should be increasingly lived and cultivated. If the ideology of Pancasila is not cultivated and practiced, then the noble values of Pancasila become normative ideals only and will never transform into daily reality in society, nation, and state. Hence, the task of the Indonesian nation today is to fight for the noble values of Pancasila so as to make it really felt and be present in reality of our everyday life.

\subsection{The Manifestation of Good Faith Principle In Transfer and Registration of Land Rights By The Government} The good faith principle by the government can be manifested in the form of good monitoring by the Ministry of Agrarian and Spatial Planning, especially the Chairmen of the National Land Agency at local levels.

The Agraria Law (UUPA) is a formal law containing the principles of agrarian law, whereas its implementing rules regulate various ways to implement these principles (Sutedi, 2014). The UUPA article Number 26 paragraph (1), UU Number 25 Year 2009, and UU Number 30 Year 2014 were issued to increase the quality of governance and support the implementation of democratic reformation, prevent the abuse of power, and ensure accountability of the government, as well as provide legal protection for people which suit the Good Governance Principle (Suparjo, 2016).

Regarding the implementation of Article 19 (1) and Article 26 (1) of the UUPA, there is no conflict of interest when the implementation of the monitoring of the land rights transfer and registration which are appropriately monitored. Monitoring can be defined as a process to ensure the objectives of the organization are achieved (Handoko, 2003).

Within the implementation of land rights transfer and registration, article 26 (1) UUPA stated that Purchase and Selling, exchange, grant, and gifts are made by the will and other actions intended to transfer the ownership 
and its monitoring regulated with the Government Regulation. This rule is a means of control for the weak or poor citizens toward other citizens whose more powerful economically. It needs to be noted that within the Article 26 (1) of this UUPA, the word "its monitoring..." is stated.

In this article, the monitoring theory used by the government (the Ministry of Agrarian and Spatial Planning) towards the implementation of land rights transfer and registration carried out by the head of the National Land Agency at various levels for RechtKadaster. Even though many scholars try to develop this theory of monitoring, monitoring is still implemented within the level of theory to analyze the performance of the National Land Agency at the city/district level in a province.

One of the most important components of the public service is external monitoring by the public, considering that the public is the receiving end of the service. When the community is aware of their rights and obligation in monitoring the public service delivery, inputs and feedback from the community will make implementing the agency of public service will try to improve their public service delivery.

The public is expected to actively participate in improving the public service delivery as they are now aware of their rights and obligations as well as they are being critical toward the monitoring of the public service that they receive. All controls and monitoring, both internally and externally in public service should complement each other and cooperate for better service delivery. Quick response and follow-up actions from the deliverer of the public service on the complaint and feedback from the community should be implemented as when internal monitoring is yet optimum then the parliaments at all levels should be quick in actions to implement their external monitoring functions.

In a legal action of legal rights transfer and registration, where a right for the land is transferred from one party to another, it should be made in front of the PPAT, including the formal agreement, which is stipulated by certain formality and existence of the authentic certificate signed in the presence of the PPAT.

The legal basis for the existence of the PPAT is Government Regulation Number 37 the Year 1997 which has been amended by Government Regulation Number 24 the Year 2016 on the Position of the Land Deed Officer.

\subsection{The Manifestation of Good Faith Principle In Transfer and Registration of Land Rights By Land Deed Official (PPAT)}

Land Deed Official (PPAT) based on the use of the professional carrying authority, as well as the legal products in the form of an authentic deed, shall refer to and be tested with the ideals of Pancasila. This could mean that any value contained in Pancasila, must be included or must be animated in every use of authority carried out by a PPAT, with no exception when he makes an authentic deed to the parties (Tedjosaputro, 1994).

Land Deed Official (PPAT) was appointed by the government, in this case, the National Land Agency with duties and authorities in order to serve the community's needs for the transfer of land rights deed (Purwaningsih, 2015). But UUPA does not regulate even absolutely not offensive about PPAT, for example in article 19 paragraph (1) of UUPA ( Boedi, 2003). Article 19 rule Number 10 the year 1961 concerning land registration does not mention PPAT and does not regulate. In Article 19 only mentions "officials"

The main task of the PPAT is to implement a part of the Land Rights Registration by creating a land deed as evidence of the implementation of a certain legal action on the land rights of the certain land unit, which serves as the basis for the registration of the land due to that legal action.

Thus, the authority of the PPAT to create authentic deed is only a part of their jobs, as stipulated in Government Regulation Number 24 Year 2016, or based on the reality where land or land rights of a housing, is not on where the parties come forward (the buyer or the seller), or where the holder of land rights reside nor where the land rights recipient reside.

Disregard the regulation on the PPAT, which has covered several regulations such as mentioned previously, the legal certainty is yet provided.

The extent of the authority of PPAT to make an authentic deed is limited by the extent of the working area of the land deed. The working area of PPAT stipulated in article 12 (1) of the Government Regulation number 24 the year 2016 for the amendment of government Regulation number 37 the year 1998 which reads "The working area of PPAT is one provincial province", but in practice, it is still difficult to implement.

Several amendments of Government Regulation Number 38 the Year 1998 are as follows;

1) Government Regulation Number 24 the Year 2016 on PPAT, which stipulates the conditions that should be obeyed by the PPAT in the implementation of their jobs,

2) Government Regulation Number Year of 2016, is a regulation on the position stated by the Article No 7 (3) of the PP No. 24 of 1997 on the Registration of the Land Rights, which mentioned: "the Regulation on the Position of the PPAT as stipulated in verse (1) is regulated separately with a Government Regulation".

3) Government Regulation Number 24 the Year 2016 on the Regulation of the Head of The National Land Agency of the Republic of Indonesia,

4) Government Regulation Number 1 the Year 2006 on Jobs Regulation of the Officer Authorized to Make 
Land Deed (PPAT), which later amended by the Regulation of the head of the National Land Agency of the Republic of Indonesia No. 23 the Year 2009.

5) Government Regulation Number 24 the Year 2016 stated; "the working area of the PPAT covers a province"

Although the arrangement of PPAT is regulated in several statutory regulations as mentioned above, but in the reality is not the creation yet of legal certainty, for example Before the regulation of the chairman of National Land agency number 8 the year 2012, About the change of regulation of the Minister of Agrarian/Chairman of National Land Agency number 3 year 1997 on government Regulation number 24 year 1997 About Land registration, One of the problems in the practice of PPAT is...... "should PPAT use the blank deed that has been specified by the government...?!"

In article 1 of the State land Agency (BPN) with regulation number 1 the year 2006, (amended in the regulation of BPN number 23 the year 2009) (amended in the regulation of BPN number 23 the year 2009), stated that... "Blank deed of PPAT made and published by BPN", thus means the BPN requires PPAT to use the blank deeds which are printed by the BPN, while PPAT wants to be allowed to make a blank deed with their own as a notary blank deed (Do not have to use BPN blank deed).

The similarities and differences of the blank deed which is printed by BPN and printed by PPAT based on Perkaban number 08 the year 2012, as listed in Figure 1 and Figure 2.

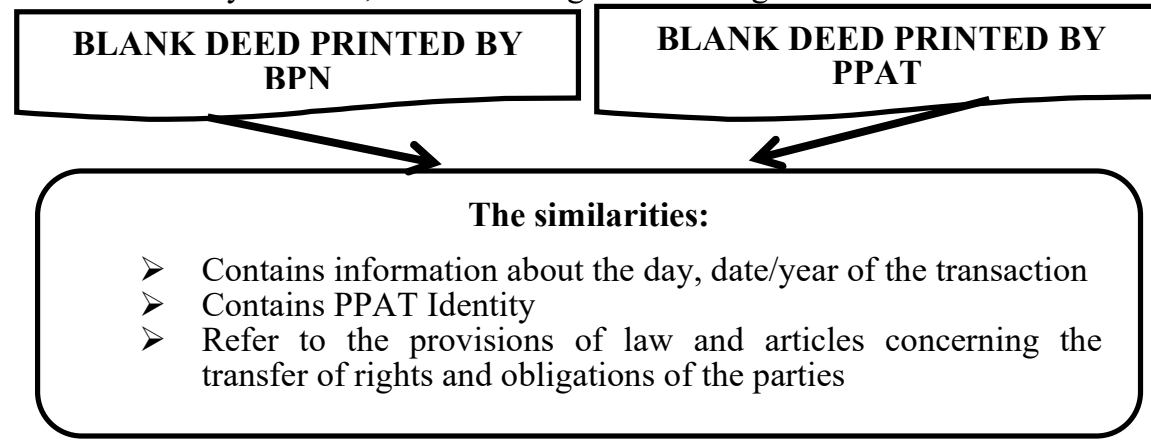

Figure 1. The similarities of the blank deed which is printed by BPN and printed by PPAT

\begin{tabular}{|c|c|}
\hline BLANK DEED PRINTED BY BPN & BLANK DEED PRINTED BY PPAT \\
\hline$\longrightarrow$ & $\longrightarrow$ \\
\hline $\begin{array}{l}\text { There is a serial number of the deeds for easy } \\
\text { tracking, in case of counterfeiting and disputes }\end{array}$ & No serial number of the deeds \\
\hline $\begin{array}{l}\text { Formal form, written completed, just fill in } \\
\text { with typewriter manually as needed }\end{array}$ & Printed by PPAT use white paper \\
\hline $\begin{array}{c}\text { No need to write down: NIB, SPPT PBB serial } \\
\text { number, land boundaries and land use }\end{array}$ & $\begin{array}{l}\text { Need to write down: NIB, SPPT PBB serial } \\
\text { number, land use, and the boundaries of land in } \\
\text { the right transitional object }\end{array}$ \\
\hline All deeds have been provided in 4 copies & $\begin{array}{l}\text { In } 2 \text { copies, one (1) copy for PPAT and another } \\
\text { one (1) copy for the concerned, as a duplicate }\end{array}$ \\
\hline $\begin{array}{c}\text { DO NOT include the name and working area } \\
\text { of PPAT on the lower left side of each sheet of } \\
\text { the deeds }\end{array}$ & $\begin{array}{l}\text { Include the name and working area of PPAT } \\
\text { on the lower left side of each sheet of the deeds }\end{array}$ \\
\hline
\end{tabular}

Figure. 2. The differences of the blank deed which is printed by BPN and printed by PPAT 
Based on Figure. 1 and Figure. 2, the Ministry of Agrarian and Spatial need to re-Draft the PPAT blank deed based on Perkaban Number 08 year 2012. In addition it is necessary the Barcode and the identity of the respective PPAT to minimize the risk of counterfeiting and misuse of the Authentic act by others.

\section{Conclusion}

Based on Pancasila perspective in article 33 paragraph (3) of the UUD 1945 Constitution states of the Republic Indonesia, manifestation of Good Faith Principle from the government, that is the Ministry of Agrarian and Spatial Planning or the Chairman of the National Land Agency, In transfer and registration of Land Rights, in form of Agrarian Agreement (UUPA) will only be achieved if the government through House of Representative (DPR) is issuing a law regarding the Land Rights Transfer or Land Ownership and PPAT Law.

\section{References}

Boedi, H. (2003). Hukum Agraria Indonesia, Sejarah Pembentukan UUPA, Isi dan Pelaksanaannya. Djambatan, Jakarta

Handoko, T.H. (2003). Manajemen. Edisi 2, cet 18. Yogyakarta: BPFE- Yogyakarta. 103 pages.

Istislam, Koeswahyono, I., Madjid, A., \& Hadiyantina, S. (2014). A New Model of Access Control Based Corporate Social Responsibility as an Instrument to Solve a Plantation Dispute (A Study in Central and East Java, Indonesia). Journal of Law, Policy, and Globalization. Vol.31.pp.18-30

Khairandi, R. (2004). Iktikad Baik Dalam Kebebasan Berkontrak. Tesis: Program Pasca Sarjana, Fakultas Hukum Unversitas Indonesia, Jakarta

Laila, F. (2016). Good Faith Dalam Perjanjian Kartu Kredit (Harapan Baru Hadirnya Otoritas Jasa Keuangan). Malang: UMM Press-Malang. 254 pages

McKendrick, E. (2018). Contract law: text, cases, and materials. London: Oxford University Press (UK)

Oesman, O., \& Alfian (1992). Pancasila Sebagai Ideologi; Dalam Berbagai Bidang Kehidupan Bermasyarakat, Berbangsa dan Bernegara. BP7 Pancasila/P4. P 379

Permadi, I. (2016). Perlindungan Hukum Terhadap Pembeli Tanah Bersertifikat Ganda Dengan Cara Itikad Baik Demi Kepastian Hukum. Yustisia Jurnal Hukum. Vol.5 (20). Pp. 448-462.

Purwaningsih, E. (2015). Keharusan Penggunaan Blangko Akta PPAT Berdasarkan Perkaban Nomor 8 Tahun 2012 Di Kabupaten Sukoharjo. Jurnal Repertorium. Edisi 3, Januari - Juni 2015.

Solikha, N.M. (2015). Asas Itikad Baik Sebagai Pembatas Kebebasan Berkontrak Dalam Perjanjian Kredit Bank. Tesis: Program Magister Ilmu Hukum. Program Pascasarjana Fakultas Hukum. Universitas Islam Indonesia, Yogyakarta.

Suharmoko (2004). Hukum Perjanjian Teori dan Analisa Kasus. Jakarta: Prenada Media. 174 pages.

Sukanto, S. (1986). Pengantar Penelitian Hukum. Universitas Indonesia, Jakarta. P.42

Sulistyarini, R., Budiono, A.R., Winarno, B., \& Koeswahyono, I. (2018). The Benchmark of Freedom of Contract under Indonesia Treaty Law (Customary Law Perspective). Journal of Law, Policy, and Globalization. Vol.8, No.2. pp.20-33

Suparjo (2016). On Land (Wealth) Distribution: A Cultural Approach to Justice in Indonesia. INDONESIA Law Review. Vol. 3, Year 1.pp. $334-347$

Sutedi A. (2014), Peralihan Hak Atas Tanah Dan Pendaftarannya. Jakarta: Sinar Grafika. 280 pages.

Tedjosaputro, L. (1994). Etika Profesi Notaris dalam Penegakan Hukum Pidana, (Yogyakarta: Bigrat Publishing, 1994),

Wiyono, S. (2016). Reaktualisasi Pancasila Dalam Kehidupan Berbangsa dan Bernegara. Penerbit Unidha Press.

Yudara, N.G. (2001). Kedudukan Akta PPAT Sebagai Alat Bukti Tertulis Yang Otentik. Makalah yang disampaikan dalam rapat INI, Jakarta, 8 Juni 2001.pp. 15-16 